\title{
PENGARUH PEMBERIAN PUPUK ORGANIK CAIR DAN EKSTRAK REBUNG TERHADAP PERTUMBUHAN DAN HASIL TANAMAN KacangPanjang (VignasinensisL.)
}

\author{
AstriceFebriantami, Nusyirwan \\ Jurusan Biologi, Program Studi Biologi, Universitas Negeri Medan Jl. William Iskandar Psr V \\ Medan Estate \\ astricefebriantami@gmail.com
}

\begin{abstract}
ABSTRAK
Penelitian ini bertujuan untuk mengetahui pengaruh pemberian pupuk hormon tanaman unggul dan ekstrak rebung terhadap pertumbuhan dan hasil tanaman kacang panjang (Vigna sinensis L.). Penelitian ini telah dilaksanakan pada bulan Februari - April 2017, di rumah kaca FMIPA Universitas Negeri Medan jalan Willem Iskandar pasar V Medan. Rancangan yang digunakan dalam penelitian ini adalah Rancangan Acak Lengkap (RAL) dengan dua faktor yaitu pupuk hantu (P) dan ekstrak rebung (R) masing-masing menggunakan 4 taraf perlakuan. Jumlah kombinasi perlakuan adalah 16 dengan ulangan 2, sehingga jumlah unit percobaan adalah 32 percobaan. Dengan menggunakan ANAVA hasil penelitian menunjukkan bahwa rata-rata jumlah daun,luas daun, jumlah bunga,jumlah buah, dan berat buah memiliki hasil yang berbeda dari masing-masing perlakuan. Untuk jumlah daun rata-rata paling tinggi terdapat pada perlakuan pupuk hantu 3ml/1L air dan ekstrak rebung $15 \mathrm{ml}$ (P3R3) dengan jumlah 25buah, luas daun rata-rata paling tinggi pada perlakuan pupuk hantu $1 \mathrm{ml} / 1 \mathrm{~L}$ air dan ekstrak rebung 0 $\mathrm{ml}$ (P1R0) dengan luas $32 \mathrm{~cm}^{2}$, jumlah bunga tanaman kacang panjang yang memiliki rata-rata paling tinggi yaitu pada perlakuan pupuk hantu $3 \mathrm{ml} / 1 \mathrm{~L}$ air dan ekstrak rebung $15 \mathrm{ml}$ (P3R3) dengan jumlah 6,5buah, jumlah polong tanaman kacang panjang yang memiliki rata-rata paling tinggi yaitu pada perlakuan pupuk hantu $3 \mathrm{ml} / 1 \mathrm{~L}$ air dan ekstrak rebung $15 \mathrm{ml}$ (P3R3) dengan jumlah 8buah, dan berat polong kacang panjang yang memiliki rata-rata paling tinggi yaitu pada perlakuan pupuk hantu $3 \mathrm{ml} / 1 \mathrm{~L}$ air dan ekstrak rebung $10 \mathrm{ml}$ (P3R2) dengan nilai 289,85gr. Hasil dari pemberian pupuk hantu dan ekstrak rebung tidak berpengaruh nyata terhadap jumlah daun, luas daun, jumlah bunga, dan jumlah buah, tetapi berpengaruh sangat nyata terhadap berat buah tanaman kacang panjang.
\end{abstract}

Kata kunci : Pupuk Hantu, Ekstrak Rebung, Tanaman Kacang Panjang.

\section{EFFECT OF LIQUID ORGANIC FERTILIZERAND BAMBOO SHOOT EXTRACT TO GROWTH AND THE YIELDOF LONG BEAN PLANT (VignasinensisL.)}

\begin{abstract}
This research is aimed to know the effect of fertilizer application of superior plant hormone and bamboo shoot extract to the growth and the yield of long bean plant (Vigna sinensis L.). This research was conducted from february - April 2017, in FMIPA's Green House, Unimed, jln.Willem Iskandar psr V, Medan. The research used Complete Randomized Design (CRD) in conducting this research by having two factors, they ware superior plant hormone (P) and bamboo shoot extract (R) which each of these ware given 4 stages of treatment. The number of combination is 16 with 2 repetitions, so that the accumulated number is 32 trials. By using ANAVA, it showed that the average numbers of the leaves, its width, its number of flower buds, the number of fruits, and its weight had different result from each treatment. The highest number of leaves is on the use of $3 \mathrm{ml}$ superior plant hormone/ $1 \mathrm{~L}$ water and 15 $\mathrm{ml}$ of bamboo shoot extract (P3R3) with the number of 25 leaves, the widest leaves are got from the use of $1 \mathrm{ml}$ superior plant hormone/ 1L water and $0 \mathrm{ml}$ of bamboo shoot extract (P1R0) it is $32 \mathrm{~cm}^{2}$, the highest number of the long bean's flower bud is got from the use of $3 \mathrm{ml}$ superior plant hormone /1 $\mathrm{L}$ water and $15 \mathrm{ml}$ bamboo shoot extract (P3R3) with the number of 6,5 buds, the highest number of the long bean's pod is got from the use of $3 \mathrm{ml}$ superior plant hormone /1L water and $15 \mathrm{ml}$ bamboo shoot extract (P3R3) with the number of 8 pods, and the weightiest weigh of the long bean's pod is got from the use of $3 \mathrm{ml}$ superior plant hormone /1L of water and $10 \mathrm{ml}$ bamboo shoot extract (P3R2) with the weight of 289,85gr. The result of giving superior plant hormone and bamboo shoot extract does not only
\end{abstract}


affect the number of leaves, the wide of the leaves, the number of flower buds, and the number of fruits significantly, but also affect the weight of the long bean itself.

Key Words: Superior Plant Hormone, Bamboo Shoot Extract, Long Bean Plant.

\section{Pendahuluan}

Indonesia merupakan sentra penanaman kacang panjang yang mempunyai keanekaragaman genetik yang luas. Berdasarkan laporan BPS, luas areal tanaman kacang-kacangan di Indonesia merupakan terluas dibandingkan dengan luas areal jenis sayuran lainnya, maka dari itu kacang panjang termasuk sayuran yang banyak dikonsumsi di Indonesia (Marmadion, dkk, 2014).

Tanaman kacang panjang (Vigna sinensis L.) merupakan salah satu komoditas sayuran yang sangat potensial untuk dikembangkan, karena mempunyai nilai ekonomi yang cukup tinggi. Dalam upaya peningkatan gizi masyarakat, kacang panjang penting sebagai sumber vitamin dan mineral. Biji kacang panjang mengandung karbohidrat $(70,00 \%)$, protein $(17,30 \%)$, lemak $(1,50 \%)$ dan air $(12,20 \%)$, sehingga komoditi ini juga merupakan sumber protein nabati (Haryanto, 2003 dalam Hakim, 2013). Selain buahnya penting sebagai sayuran, daun muda dari kacang panjang juga sangat bagus untuk dijadikan sayuran yang memiliki kandungan serat dan vitamin yang tinggi, untuk bijinya menjadi salah satu sumber protein nabati. Selain itu tanaman ini juga dapat menyuburkan tanah, pada akar kacang panjang terdapat bintil-bintil akar yang berisi bakteri Rhizobium sp. yang dapat menambat nitrogen bebas dari udara dan merubahnya menjadi bentuk yang dibutuhkan tanaman.

Menurut data statistik dari BPS dan Direktorat Jendral Holtikultura, produktivitas sayuran kacang panjang di Indonesia pada tahun 2011 mencapai 5,76 ton/Ha, tahun 2012 mencapai 6,02 ton/Ha, tahun 2013 mencapai 5,92 ton/Ha, tahun 2014 mencapai 6,22, tahun 2015 mencapai 6,26 ton/Ha.

Tingkat rata-rata produktivitas kacang panjang yang dihasilkan di Indonesia yaitu sebesar 6,26 ton per hektar. Menurut informasi yang didapatkan melalui petugas penyuluh lapang (PPL) tingkat produktivitas kacang panjang masih bisa ditingkatkan dan optimalnya mampu mencapai 15-20 ton/Ha, kondisi ini menyebabkan adanya kesenjangan (Gap) yang akan berdampak pada tingkat pendapatan yang diperoleh petani (Kamil, 2013). Sehingga petani tidak mendapatkan hasil yang cukup baik untuk pemanenan kacang panjang.

Produksi kacang panjang dapat ditingkatkan agar tidak terjadi kesenjangan bagi pendapatan yang diperoleh petani dan dapat menjadi salah satu sayuran yang mudah didapat oleh masyarakat dengan kualitas yang baik dengan upaya budidaya tanaman yang tepat, termasuk aspek pemeliharaan diantaranya yaitu pemupukan. Dewasa ini pupuk yang banyak beredar dipasaran adalah pupuk anorganik atau pupuk kimia. Pemakaian pupuk kimia dalam jangka waktu yang lama dapat merusak ekosistem tanah. Penggunaan pupuk kimia juga dapat menambah keasaman tanah yang menyebabkan banyak mikroorganisme tanah yang mati. Berkurangnya mikroorganisme dalam tanah menyebabkan berkurangnya pasokan unsur hara yang dapat diserap oleh tanaman, sehingga tanaman tidak subur dan produksinya berkurang.

Untuk mengatasi hal tersebut agar produksi kacang panjang semakin meningkat dan tidak merusak tanah, pemupukan merupakan salah satu alternatif untuk meningkatkan hasil produksi kacang panjang dan kapasitas produksi tanah. Pemupukan tersebut dapat berupa pupuk organik, pupuk anorganik, ataupun campuran keduanya. Pemupukan yang efektif melibatkan persyaratan kuantitatif dan kualitatif. Persyaratan kuantitatifnya adalah dosis pupuk, sedangkan persyaratan kualitatifnya meliputi unsur hara yang diberikan dalam pemupukan relevan dengan masalah nutrisi yang ada, waktu pemupukan dan penempatan pupuk tepat, unsur hara dapat diserap tanaman, tanaman dapat menggunakan unsur hara yang diserap untuk meningkatkan produksi dan kualitasnya (Setiyono, 2015).

Menurut Setiyono (2015) menyatakan bahwa penggunaan pupuk organik biasanya ditujukan untuk memperbaiki sifat fisik, dan biologi tanah. Walaupun kandungan unsur hara dalam pupuk organik relatif lebih kecil dibanding pupuk anorganik namun bila sifat 
fisik menjadi baik maka sifat kimia tanah pun akan berubah. Pupuk organik dapat menambah kandungan bahan organik tanah dan memperbaiki sifat fisik maupun biologi tanah.

Penelitian ini menggunakan pupuk organik yaitu pupuk hormon tanaman unggul dan ekstrak rebung sebagai pengganti pupuk kimia dan perangsang pertumbuhan yang selama ini digunakan untuk menanam tanaman kacang panjang, pupuk hormon tanaman unggul merupakan pupuk organik yang diperuntukkan bagi semua jenis tanaman. Pupuk Hantu dibuat dari sari tumbuh-tumbuhan herbal (Sujimin, 2010 dalam Kartika, dkk, 2013). Pupuk organik ini mengandung unsur hara makro dan mikro, juga mengandung zat pengatur tumbuh yang dapat meningkatkan perkecambahan benih dan pertumbuhan kecambah sampai menjadi bibit yang siap untuk dipindahkan ke lapangan. Sedangkan rebung dapat sebagai pengganti hormon giberelin yang dapat berpengaruh pada perkembangan dan perkecambahan, serta berfungsi memperbesar ukuran buah, merangsang pembentukan bunga dan mengakhiri masa dormansi biji (Maretza, 2009).

Berdasarkan latar belakang diatas, maka akan dilakukannya penelitian dengan judul "Pengaruh Pemberian Pupuk Hormon Tanaman Unggul dan Ekstrak Rebung Terhadap Pertumbuhan serta Hasil Tanaman Kacang Panjang(Vigna sinensis L.) ", dengan dilakukannya penelitian ini dapat meningkatkan potensi produktivitas kacang panjang dan menyuburkan tanah.

\section{Bahan dan Metode}

Penelitian ini telah dilaksanakan di rumah kaca Biologi Fakultas Matematikan dan Ilmu Pengetahuan Alam, Universitas Negeri Medan. Penelitian ini dilakukan pada bulan Februari 2017- April 2017. Dimana, Rancanan yang digunakan dalam penelitian ini adalah Rancangan Acak Lengkap Faktorial dengan perlakuan pupuk organik cair (Hantu) dan Ekstrak Rebung.

Berdasarkan petunjuk penggunaan dari produk, maka dosis pupuk organik cair(Hantu) yang digunakan dalam penelitian ini adalah P0 = Tanpa pupuk organik cair (Hantu), P1 = pupuk organik cair (Hantu) $1 \mathrm{ml}$ dilarutkan dalam $1 \mathrm{~L}$ air, P2 = pupuk organik cair (Hantu) $2 \mathrm{ml}$ dilarutkan dalam $1 \mathrm{~L}$ air, dan $\mathrm{P} 3$ = pupuk organik cair (Hantu) $3 \mathrm{ml}$ dilarutkan dalam 1 L air. Berdasarkan Maretza (2009), maka dosis ekstrak rebung yang digunakan dalam penelitian ini adalah R0 = Tanpa ekstrak rebung, R1 = Ekstrak rebung $5 \mathrm{ml}, \mathrm{R} 2=$ Ekstrak rebung $10 \mathrm{ml}, \mathrm{R} 3=$ Ekstrak rebung $15 \mathrm{ml}$.

Dalampenelitianini, terdiridari 16 perlakuan, 2 kali pengulangan, dan 32 unitpercobaandimanasetiap unit percobaanterdiridari1

tanamankacangpanjang. Penelitian diawali dengan peyemaian benih kacangpanjang selama \pm 1 minggu, kemudian kacang panjang yang telah tumbuh didalam polybag yang telah diisi tanah, dandiamatiselama 7 minggu. Parameter yang diamatiadalah: 1. Jumlah daun kacang panjang, jumlah daun yang di hitung dari satu tanaman adalah daun yang bagus, parameter ini untuk mengetahui pertumbuhan tanaman kacang panjang. 2 . Luas Daun kacang panjang, daun yang diukur menggunakan kertas milimeter dan setiap satu tanaman dipilih daun yang paling besar dan bagus, parameter ini untuk mengetahui pertumbuhan tanaman kacang panjang. 3 . Jumlah bunga muncul, penghitungan bunga dihitung dari bunga yang pertama kali muncul sampai terakhir pengamatan, parameter ini untuk mengetahui pertumbuhan tanaman kacang panjang. 4. Jumlah buah kacang panjang perpohon, perhitungan jumlah buah dilakukan pada saat panen yaitu pada minggu ke 6 sampai minggu ke 7, pemanenan dillakukan 1 kali. Penghitungan jumlah buah dilakukan dengan menghitung seluruh buah yang dipetik dari masing-masing pohon, parameter ini untuk mengetahui hasil tanaman kacang panjang. 5. Berat buah kacang panjang perpohon, pengukuran berat kacang panjang dilakukan pada saat setelah panen. Pengukuran berat buah dilakukan dengan menimbang seluruh buah yang dipetik dari masing-masing pohon, parameter ini untuk mengetahui hasil tanaman kacang panjang.

Pembuatan ekstrak rebung dilakukan dengan cara mencacah rebung sebanyak $1 \mathrm{~kg}$, kemudian menambahkan air sebanyak 1 liter lalu direbus hingga matang. Memblender rebung matang dan air rebusan 
rebung tadi, kemudian menambahkan 1 liter air matang lagi. Memeras dan menyaring ekstrak rebung yang diblender tadi dengan menggunakan saringan hingga terpisah air ekstrak rebung dengan limbah padatnya. Air ekstrak rebung siap digunakan (Maretza, 2009).

Pemberian pupuk organik cair (Hantu) dan ekstrak rebung dilakukan dengan cara menyiramkan ekstrak rebung dengan dosis 5 $\mathrm{ml}, 10 \mathrm{ml}$ dan $15 \mathrm{ml}$ pada masing-masing tanaman. Setelah ekstrak rebung di siramkankan, kemudian dilakukan pula penyemprotan dengan pupuk organik cair (Hantu) dosis $1 \mathrm{ml}, 2 \mathrm{ml}$ dan $3 \mathrm{ml}$ yang masing-masing dilarutkan dalam $1 \mathrm{~L}$ air. Ekstrak rebung dan pupuk organik cair (hantu) di berikan dengan interval 7 hari sekali. Adapun parameter yang diamati dalam penelitian adalah jumlah daun, luas daun, dan jumlah bunga.

Data yang diperoleh dari penelitian ditabulasikan kemudian dianalisis dengan analisis varians (ANAVA). Pengolahan data dilakukan dengan bantuan Ms. excel.

\section{Hasil dan Pembahasan Hasil}

Dari penelitian yang telah dilakukan, maka didapatkan hasil penelitian sebagai berikut:

Tabel 1.Daftar Analisis Ragam Jumlah Helai Daun Tanaman KacangPanjang Minggu ke 7 yang diberi Kombinasi Perlakuan pupuk organik cair(Hantu) dan Ekstrak Rebung

\begin{tabular}{|l|cccccc|}
\hline $\begin{array}{l}\text { Sumber } \\
\begin{array}{l}\text { Keraga } \\
\text { man }\end{array}\end{array}$ & $\mathrm{dB}$ & $\begin{array}{c}\text { Jumla } \\
\mathrm{h} \\
\text { Kuadr } \\
\text { at }\end{array}$ & $\begin{array}{c}\text { Kuad } \\
\text { rat } \\
\text { Teng } \\
\text { ah }\end{array}$ & $\begin{array}{c}\mathrm{F} \\
\text { hit }\end{array}$ & $\begin{array}{c}\text { F Tabel } \\
0,0\end{array}$ & 0,0 \\
5 & 1 \\
\hline $\begin{array}{l}\text { Perlaku } \\
\text { an }\end{array}$ & 15 & 322.88 & - & - & - & - \\
$\begin{array}{l}\text { Faktor } \\
\text { A }\end{array}$ & 3 & 113.13 & 37.71 & 0.50 & 3,24 & 5,29 \\
Faktor & 3 & 41.63 & 13.87 & $\begin{array}{c}0.18 \\
\text { tn }\end{array}$ & 3,24 & 5,29 \\
$\begin{array}{l}\text { B } \\
\text { Interak } \\
\text { si }\end{array}$ & 9 & 168.12 & 18.68 & 0.25 & 2,54 & 3,78 \\
Galat & 16 & 1195 & 74.68 & - & - & - \\
Total & 31 & 1517.8 & - & - & - & - \\
& & 8 & & & & \\
\hline
\end{tabular}

Keterangan : tn $^{-}$tidak berpengaruh nyata

Berdasarkan tabel diatas dapat dilihat bahwa pada faktor $A F_{\text {hitung }}=(0,50)$ dan $F_{\text {tabel }}$ $0,05=(3,24)$. Pada faktor $B F_{\text {hitung }}=(0,18)$ dan $F_{\text {tabel }} 0,05=(3,24)$. Pada interkasi $F_{\text {hitung }}=$
$(0,25)$ sedangkan $F_{\text {tabel }} 0,05(2,54)$. dari data tersebut diperoleh bahwa faktor A, faktor $\mathrm{B}$, dan interaksi semuanya memiliki $F_{\text {hitung }}<\mathrm{F}_{\text {tabel }}$ pada taraf kepercayaan 95\%, maka $\mathrm{H}_{0}$ diterima dan $\mathrm{H}_{\mathrm{a}}$ ditolak, berarti tidak terdapat pengaruh pupuk hantu, ekstrak rebung, dan interaksi terhadap jumlah daun tanaman kacang panjang. Karena tidak terdapat pengaruh nyata atau sangat nyata maka tidak perlu dilakukan uji BNT atau uji lanjut lainnya.

Tabel 2.Daftar Analisis Ragam Luas Daun TanamanKacangPanjang Minggu ke 4 yang diberi Kombinasi Perlakuan pupuk organik cair (Hantu) dan Ekstrak Rebung

\begin{tabular}{|l|cccccc|}
\hline $\begin{array}{c}\text { Sumber } \\
\text { Keragama } \\
\mathrm{n}\end{array}$ & $\mathrm{dB}$ & $\begin{array}{c}\text { Jumlah } \\
\text { Kuadrat }\end{array}$ & $\begin{array}{c}\text { Kuadra } \\
\mathrm{t} \\
\text { Tenga } \\
\mathrm{h}\end{array}$ & $\mathrm{F}$ hit & \multicolumn{2}{c|}{$\mathrm{F}$ Tabel } \\
\hline Perlakuan & 15 & 246.72 & - & - & - & - \\
Faktor A & 3 & 25.59 & 8,53 & 0.10 & 3,24 & 5,29 \\
Faktor B & 3 & 37.84 & 12.61 & 0.15 & 3,24 & 5,29 \\
Interaksi & 9 & 183.29 & 20.36 & 0.25 & 2,54 & 3,78 \\
Galat & 16 & 1290.5 & 80.65 & - & - & - \\
Total & 31 & 1537.22 & - & - & - & - \\
\hline
\end{tabular}

Keterangan : ${ }^{\mathrm{tn}}=$ tidak berpengaruh nyata

Berdasarkan tabel diatas dapat dilihat bahwa pada faktor $A F_{\text {hitung }}=(0,10)$ dan $F_{\text {tabel }}$ $0,05=(3,24)$. Pada faktor $B F_{\text {hitung }}=(0,15)$ dan $F_{\text {tabel }} 0,05=(3,24)$. Pada interkasi $F_{\text {hitung }}=$ $(0,25)$ sedangkan $F_{\text {tabel }} 0,05(2,54)$. Dari data tersebut diperoleh bahwa faktor A, faktor B, dan interaksi semuanya memiliki $F_{\text {hitung }}<F_{\text {tabel }}$ pada taraf kepercayaan 95\%, maka $\mathrm{H}_{0}$ diterima dan $\mathrm{H}_{\mathrm{a}}$ ditolak, berarti tidak terdapat pengaruh pupuk hantu, ekstrak rebung, dan interaksi terhadap luas daun tanaman kacang panjang. Karena tidak terdapat pengaruh nyata atau sangat nyata maka tidak perlu dilakukan uji BNT atau uji lanjutan lainnya.

Tabel 3.Daftar Analisis Ragam Jumlah Bunga Tanaman KacangPanjang Minggu ke 7 yang diberi Kombinasi Perlakuan pupuk organik cair (Hantu) dan Ekstrak Rebung

\begin{tabular}{|l|cccccc|}
\hline $\begin{array}{l}\text { Sumb } \\
\text { er } \\
\text { Kerag } \\
\text { aman }\end{array}$ & dB & Jumlah & Kuadr & F hit & \multicolumn{2}{c|}{ F Tabel } \\
Kadrat & $\begin{array}{c}\text { at } \\
\text { Tenga } \\
\text { h }\end{array}$ & & 0,05 & 0,01 \\
\hline $\begin{array}{l}\text { Perla } \\
\text { kuan }\end{array}$ & 15 & 61.88 & - & - & - & - \\
$\begin{array}{l}\text { Fakto } \\
\text { r A }\end{array}$ & 3 & 23.13 & 7.71 & $3.17^{\text {tn }}$ & 3,24 & 5,29 \\
$\begin{array}{l}\text { Fakto } \\
\text { r B }\end{array}$ & 3 & 5.38 & 1.79 & $0.73^{\text {tn }}$ & 3,24 & 5,29 \\
Intera & 9 & 33.37 & 3.70 & $1.52^{\text {tn }}$ & 2,54 & 3,78
\end{tabular}


ksi

\begin{tabular}{l|lll} 
Galat & 16 & 39 & 2.43
\end{tabular}

$\begin{array}{lll}\text { Total } & 31 & 100.88\end{array}$

Keterangan $^{\text {tn }}=$ tidak berpengaruh nyata

Berdasarkan tabel diatas dapat dilihat bahwa pada faktor $A F_{\text {hitung }}=(3,17)$ dan $F_{\text {tabel }}$ $0,05=(3,24)$. Pada faktor $B F_{\text {hitung }}=(0,73)$ dan $F_{\text {tabel }} 0,05=(3,24)$. Pada interkasi $F_{\text {hitung }}=$ $(1,52)$ sedangkan $F_{\text {tabel }} 0,05(2,54)$. dari data tersebut diperoleh bahwa faktor A, faktor B, dan interaksi semuanya memiliki $\mathrm{F}_{\text {hitung }}<\mathrm{F}_{\text {tabel }}$ pada taraf kepercayaan 95\%, maka $\mathrm{H}_{0}$ diterima dan $\mathrm{H}_{\mathrm{a}}$ ditolak, berarti tidak terdapat pengaruh pupuk hantu, ekstrak rebung, dan interaksi terhadap jumlah bunga tanaman kacang panjang. Karena tidak terdapat pengaruh nyata atau sangat nyata maka tidak perlu dilakukan uji BNT atau uji lanjutan lainnya.

Tabel 4.Daftar Analisis Ragam BeratBuah Tanaman KacangPanjang Minggu ke 7 yang diberi Kombinasi Perlakuan pupuk organik cair (Hantu) dan Ekstrak Rebung

\begin{tabular}{|c|c|c|c|c|c|c|}
\hline \multirow{2}{*}{$\begin{array}{l}\text { Sumber } \\
\text { keragaman }\end{array}$} & \multirow[t]{2}{*}{$\mathrm{db}$} & \multirow[t]{2}{*}{ JK } & \multirow[t]{2}{*}{ KT } & \multirow{2}{*}{$\begin{array}{l}\text { Fhitu } \\
\text { ng }\end{array}$} & \multicolumn{2}{|c|}{$\mathrm{F}_{\text {tabel }}$} \\
\hline & & & & & $\begin{array}{l}0,0 \\
5\end{array}$ & $\begin{array}{l}0,0 \\
1\end{array}$ \\
\hline Perlakuan & 15 & $\begin{array}{l}1271 \\
63\end{array}$ & - & - & - & - \\
\hline Faktor A & 3 & $\begin{array}{l}7877 \\
8.6\end{array}$ & $\begin{array}{l}2625 \\
9.5\end{array}$ & $\begin{array}{l}24 . \\
8^{* *}\end{array}$ & $\begin{array}{l}3,2 \\
4\end{array}$ & $\begin{array}{l}5,2 \\
9\end{array}$ \\
\hline Faktor B & 3 & $\begin{array}{l}2423 \\
1.6\end{array}$ & $\begin{array}{l}8077 \\
.2\end{array}$ & $\begin{array}{l}7.6 \\
3^{* *}\end{array}$ & $\begin{array}{l}3,2 \\
4\end{array}$ & $\begin{array}{l}5,2 \\
9\end{array}$ \\
\hline Interaksi & 9 & 2415 & 2683 & $\begin{array}{l}2.5 \\
4 \mathrm{tn}\end{array}$ & $\begin{array}{l}2,5 \\
4\end{array}$ & 3,7 \\
\hline $\begin{array}{l}\mathrm{AB} \\
\text { Galat }\end{array}$ & 16 & $\begin{array}{l}2.8 \\
1692 \\
6.5\end{array}$ & $\begin{array}{l}.6 \\
1057 \\
.9\end{array}$ & $\begin{array}{l}4 \text { tn } \\
-\end{array}$ & $\begin{array}{l}4 \\
-\end{array}$ & $\begin{array}{l}8 \\
-\end{array}$ \\
\hline Total & 31 & $\begin{array}{l}1440 \\
89.5\end{array}$ & - & - & - & - \\
\hline
\end{tabular}

Keterangan $^{\mathrm{tn}}=$ tidak berpengaruh nyata

Berdasarkan tabel diatas dapat dilihat bahwa pada faktor $A F_{\text {hitung }}=(24,8)$ dan $F_{\text {tabel }} 0,01=$ $(5,29)$. Pada faktor $B F_{\text {hitung }}=(7,63)$ dan $F_{\text {tabel }}$ $0,01=(5,29)$. Dari data tersebut diperoleh bahwa faktor A dan faktor B memiliki $F_{\text {hitung }}>$ $\mathrm{F}_{\text {tabel }}$ pada taraf kepercayaan $99 \%$, maka $\mathrm{H}_{0}$ ditolak dan $\mathrm{H}_{\mathrm{a}}$ diterima, berarti terdapat pengaruh pupuk hantu dan ekstrak rebung terhadap berat polong tanaman kacang panjang. Pada interaksi $\mathrm{F}_{\text {hitung }}=(2,54)$ sedangkan $F_{\text {tabel }} 0,05(2,54)$. Dari data tersebut memiliki $F_{\text {hitung }}=F_{\text {tabel, }}$ maka $\mathrm{H}_{0}$ diterima dan $\mathrm{H}_{\mathrm{a}}$ ditolak, berarti tidak terdapat pengaruh interaksi terhadap berat polong tanaman kacang panjang. Karena terdapat pengaruh nyata maka perlu dilakukan uji BNT.

\begin{tabular}{|l|c|c|cc|}
\hline Pengaruh & Perlakuan & Rataan & \multicolumn{2}{|c|}{ Notasi } \\
\hline Ekstrak & P0R1 & 54.35 & 54.35 & ab \\
rebung & P0R2 & 74.3 & 74.3 & abc \\
& P0R3 & 74.4 & 74.4 & abc \\
\hline Pupuk & P1R0 & 74.2 & 74.2 & abc \\
hantu & P2R0 & 130 & 130 & cd \\
& P3R0 & 133.7 & 133.7 & cd \\
\hline Interaksi & P1R3 & 117.25 & 117.25 & bcd \\
& P1R1 & 48.2 & 48.2 & a \\
& P2R1 & 140.1 & 140.1 & cd \\
& P2R2 & 126.5 & 126.5 & cd \\
& P2R3 & 144.2 & 144.2 & d \\
& P1R2 & 122.4 & 122.4 & bcd \\
& P3R1 & 120 & $120 \mathrm{~b}$ & cd \\
& P3R2 & 289.85 & 289.85 & e \\
& P3R3 & 228.8 & 228.8 & e \\
\hline
\end{tabular}

Keterangan: Angka yang diikuti oleh notasi yang sama pada setiap perlakuan yang berbeda menunjukkan tidak berbeda nyata pada taraf $5 \%$ menurut uji BNT.

Berdasarkan tabel 4.6 dilihat bahwa rata-rata bobot polong tanaman kacang panjang pada perlakuan interaksi antara pupuk hantu dan ekstrak rebung tertinggi umur 42-50 hari adalah perlakuan P3R2 yaitu 289.85gr, sedangkan yang terendah adalah perlakuan P1R1 yaitu 48,2gr. Pada tabel 4.6 menunjukkan perlakuan interaksi antara perlakuan pupuk hantu dan ekstrak rebung pada perlakuan P3R2 berbeda nyata pada perlakuan lainnya terhadap bobot polong kacang panjang umur 42-50 HST. Pada tabel 4.6 dapat dilihat bahwa rata-rata bobot polong tanaman kacang panjang pada perlakuan tunggal pupuk hantu tertinggi adalah perlakuan P3R0 yaitu 133,7gr, sedangkan yang terendah diperoleh pada perlakuan P1R0 yaitu 74,2. Pada tabel 4.6 menunjukkan bahwa pengaruh tunggal pupuk hantu pada perlakuan P3R0 berbeda nyata dengan perlakuan P1R0, tetapi tidak berbeda nyata dengan perlakuan P2R0 terhadap bobot polong kacang panjang. Pada tabel 4.6 dapat dilihat bahwa rata-rata bobot polong tanaman kacang panjang pada perlakuan tunggal ekstrak rebung tertinggi adalah perlakuan P0R3 yaitu 74,4gr, sedangkan yang terendah diperoleh pada perlakuan P0R1 yaitu 54,35gr. Pada tabel 4.6 menunjukkan bahwa pengaruh 
tunggal ekstrak rebung pada perlakuan P0R3 berbeda nyata dengan perlakuan P0R1, tetapi tidak berbeda nyata dengan perlakuan P0R2 terhadap bobot polong kacang panjang.

\section{Pembahasan}

\section{Deskrispsi Pengaruh Pemberian Pupuk Hantu dan Ekstrak Rebung terhadap Jumlah Helai Daun}

Daun merupakan organ yang penting dalam pertumbuhan tanaman, semakin banyak jumlah daun, mengindikasikan tumbuhan semakin baik (Yeremia, 2016). Dan jika jumlah daun semakin sedikit mengindikasikan tanaman tidak mendapatkan unsur yang sesuai dengan kebutuhannya. Karena di daunlah terjadi proses fotosintesis yang digunakan untuk perkembangan dan pertumbuhan tanaman, antara lain pertambahan ukuran dan tinggi tanaman, pembentukan cabang dan daun baru.

Pemberian pupuk hantu dan ekstrak rebung tidak memberikan pengaruh nyata terhadap jumlah daun disebabkan karena $\mathrm{pH}$ dan lingkungan tanaman, $\mathrm{pH}$ yang terdapat pada ekstrak rebung memiliki $\mathrm{pH}$ asam yaitu 4, dan dengan $\mathrm{pH}$ asam tanah mengalami kerusakan dan dapat berpengaruh pada pertumbuhan tanaman, lingkungan pada rumah kaca juga berpengaruh pada pertumbuhan tanaman kacang panjang dimana suhu yang terdapat dirumah kaca terlalu tinggi, sehingga tanaman cepat mengalami kekeringan. Kekurangan air akan menyebabkan tanaman menjadi layu dan proses pertambahan tinggi dan jumlah daun juga terhambat.

Nitrogen adalah salah satu unsur makro yang dibutuhkan tanaman dalam jumlah yang banyak dan diserap dalam bentuk ion $\mathrm{NH}_{4}{ }^{+}$dan $\mathrm{NO}_{3}{ }^{-}$. Dalam pertumbuhan dan perkembangan daun unsur $\mathrm{N}$ paling berpengaruh. Konsentrasi $\mathrm{N}$ yang tinggi umumnya menghasilkan daun yang lebih besar dan lebar (Lakitan, 1996). Unsur N merupakan unsur hara yang mendapat banyak perhatian, ini dikarenakan jumlah $\mathrm{N}$ yang terdapat didalam tanah sedikit, sedangkan dalam kebutuhan tanaman dan kehilangan $\mathrm{N}$ dalam tanah cukup besar (Barus, dkk, 2013). Sedangkan pada pupuk hantu hanya mengandung $0,011 \%$ nitrogen dan pada ekstrak rebung tidak terdapat kandungan nitrogen yang cukup, karena jika hanya mengandalkan nitrogen pada tanah dan pupuk hantu tidak cukup untuk memenuhi kebutuhan akan tanaman tersebut, juga dikarenakan tempat tanam untuk tanaman kacang panjang yang tidak terlalu besar, sehingga persediaan akan unsur $\mathrm{N}$ tidak tinggi, dan pemberian nitrogen dari luar juga tidak memenuhi kebutuhan kacang panjang. Sehingga proses fotosintesis tidak menghasilkan hasil yang baik untuk pertumbuhan tanaman, dan produksi daun maupun buah akan menurun. Menurut penelitian Maretza, (2009) pemberian ekstrak rebung tidak memberikan pengaruh nyata terhadap jumlah daun semai sengon.

Berdasarkan gambar hasil tertinggi dari pemberian pupuk hantu dan ekstrak rebung terdapat pada kombinasi perlakuan pupuk hantu $3 \mathrm{ml} / 1 \mathrm{~L}$ air dan ekstrak rebung $15 \mathrm{ml}$ (P3R3).

\section{Deskripsi Pengaruh Pemberian Pupuk hantu dan ekstrak rebung terhadap luas} daun

Daun pada tanaman memiliki peranan yang sangat penting dalam proses fotosintesis, daun sebagai tempat mensistesis makanan untuk kebutuhan tanaman dan sebagai cadangan makanan, semakin banyak jumlah daun dan semakin lebar daun maka akan semakin cepat proses fotosintesis.

Reaksi fotosintesis $6 \mathrm{CO}_{2}+6 \mathrm{H}_{2} \mathrm{O}_{2} \longrightarrow \mathrm{C}_{6} \mathrm{H}_{12} \mathrm{O}_{6}$ $+60_{2}$

Kandungan NPK pada tanaman akan mempengaruhi lebarnya daun, jika kandungan NPK memenuhi kebutuhan tanaman, maka daun akan semakin lebar dan proses fotosintesis akan berjalan cepat (Yeremia, 2016). Pada proses fotosintesis menghasilkan glukosa dan air yang diangkut oleh pembuluh floem untuk diedarkan keseluruh tubuh tumbuhan, hasil fotosintesis ini sangat dibutuhkan oleh tumbuhan untuk pertumbuhan dan perkembangannya. Sehingga jika tumbuhan kekurangan unsur hara baik makro maupun mikro dan proses fotosintesis terganggu maka akan mempengaruhi pertumbuhan dan perkembangan tanaman.

Pemberian pupuk hantu dan ekstrak rebung tidak memberikan pengaruh nyata terhadap jumlah daun disebabkan karena $\mathrm{pH}$ dan lingkungan tanaman yang berpengaruh terhadap proses fotosintesis, $\mathrm{pH}$ yang 
terdapat pada ekstrak rebung memiliki $\mathrm{pH}$ asam yaitu 4, sedangkan untuk pertumbuhan yang optimum, diperlukan derajat keasaman $(\mathrm{pH})$ tanah antara 5,5 - 6,5. Bila $\mathrm{pH}$ di bawah 5,5 dapat menyebabkan tanaman tumbuh kerdil karena teracuni garam aluminium (Al) yang larut dalam tanah (Haryanto, 2003 dalam Setiyono, 2015). Lingkungan pada rumah kaca juga berpengaruh pada pertumbuhan tanaman kacang panjang, yaitu dengan suhu yang terlalu tinggi, sehingga tanaman cepat mengalami kekeringan. Kekurangan air akan menyebabkan tanaman menjadi layu dan proses fotosintesis terganggu, sehingga berpengaruh pada pertumbuhan perkembangan tanaman.

Berdasarkan gambar hasil tertinggi dari pemberian pupuk hantu dan ekstrak rebung terdapat pada kombinasi perlakuan pupuk hantu $3 \mathrm{ml} / 1 \mathrm{~L}$ air dan ekstrak rebung $15 \mathrm{ml}$ (P3R3).

\section{Deskripsi Pengaruh Pemberian Pupuk hantu dan ekstrak rebung terhadap jumlah bunga}

Bunga pada tumbuhan berbunga sebagai alat reproduksi seksual, pada bunga terdapat organ reproduksi berupa benang sari dan putik, dan bunga akan menghasilkan bakal buah yang akan berkembang menjadi buah yang menghasilkan biji.

Nitrogen adalah salah satu unsur makro yang dibutuhkan tanaman dalam jumlah yang banyak dan diserap dalam bentuk ion $\mathrm{NH}_{4}{ }^{+}$dan $\mathrm{NO}_{3}{ }^{-}$. Dalam pertumbuhan dan perkembangan daun unsur $\mathrm{N}$ paling berpengaruh. Konsentrasi N yang tinggi umumnya menghasilkan daun yang lebih besar dan lebar (Lakitan, 1996). Semakin lebar luas daun maka proses fotosintesis semakin baik dan akan menghasilkan produk untuk perkembangan bunga. Unsur $\mathrm{N}$ merupakan unsur hara yang mendapat banyak perhatian, ini dikarenakan jumlah $\mathrm{N}$ yang terdapat didalam tanah sedikit, sedangkan dalam kebutuhan tanaman dan kehilangan $\mathrm{N}$ dalam tanah cukup besar (Barus, dkk, 2013). Sedangkan pada pupuk hantu hanya mengandung $0,011 \%$ nitrogen dan pada ekstrak rebung tidak terdapat kandungan nitrogen yang cukup, karena jika hanya mengandalkan nitrogen pada tanah dan pupuk hantu tidak dapat memenuhi kebutuhan akan tanaman tersebut, juga dikarenakan tempat tanam untuk tanaman kacang panjang yang tidak terlalu besar, sehingga persediaan akan unsur $\mathrm{N}$ tidak tinggi, dan pemberian nitrogen dari luar juga tidak memenuhi kebutuhan kacang panjang. Sehingga pertumbuhan tanaman akan terganggu, dan produksi daun maupun buah akan menurun.

Berdasarkan gambar hasil tertinggi dari pemberian pupuk hantu dan ekstrak rebung terdapat pada kombinasi perlakuan pupuk hantu $3 \mathrm{ml} / 1 \mathrm{~L}$ air dan ekstrak rebung $15 \mathrm{ml}$ (P3R3).

\section{Kesimpulan Dan Saran Kesimpulan}

Dari hasil penelitian pemberian pupuk organik cair (Hantu) dan ekstrak rebung diperoleh kesimpulan sebagai berikut:

1. Pemberian pupuk hantuberpengaruhnyataterhadapberatbua $h$, tetapi tidak berpengaruh nyata terhadap jumlah daun, luas daun,danjumlahbunga.

2. Pemberian

ekstrak rebungberpengaruhnyataterhadapberatbu ah, tetapi tidak berpengaruh nyata terhadap jumlah daun, luas daun, danjumlahbunga,

3. Interaksi antara pemberian Pupuk hantu dan ekstrak rebung tidak memberikan Saran pengaruh nyata terhadap

Perlu dilakukan penelitian lebih lanjut mengenai penentuan kandungan unsur hara mikro dan makro yang terdapat pada ekstrak rebung.

\section{Daftar Pustaka}

Ashari, S., (1995). Hortikultura Aspek Budidaya. Universitas Indonesia Press, Jakarta.

Barus, N., Damanik, M, M, B., dan Supriadi., (2013). Ketersediaan Nitrogen Akibat Pemberian berbagai Jenis Kompos pada Tiga Jenis Tanah dan Efeknya terhadap Pertumbuhan Tanaman Jagung (Zea mays L.), Jurnal online Agroekotekhnologi, 1 (3).

Dewi, I, R., (2008). Peranan dan Fungsi Fitohormon bagi Pertumbuhan 
Tanaman, Fakultas Pertanian Universitas Padjajaran, Bandung.

Direktorat Jenderal Hortikultura, (2017), Statistik Produksi Hortikultura 2015, Departemen Pertanian, Jakarta.

Hakim, I., (2013). Pertumbuhan dan Hasil Tanaman Kacang Panjang (Vigna sinensisL.) Varietas Kanton Melalui Pemberian Pupuk Petrobio Gr. Skripsi, Universitas Negeri Gorontalo.

Hardjowigeno, S,. (2003). Klasifikasi tanah dan pedogenesis. Akademik Pressindo. Jakarta.

Kamil, D, S., (2013). Analisis Faktor- Faktor yang Mempengaruhi Produksi dan Pendapatan Usaha tani Kacang Panjang., Skripsi, Fakultas Ekonomi dan Manajemen, IPB, Bogor.

Kartika, E., Gani, Z., dan Kurniawan, D. (2013). Tanggapan Tanaman Tomat (Lycopersicum esculentum M.) Terhadap Pemberian Kombinasi Pupuk Organik Dan Pupuk Anorganik, Agroekoteknologi Fakultas Pertanian Universitas Jambi,2 (3), ISSN :23026472

Maretza, D, T. (2009), Pengaruh Dosis Ekstrak Rebung Bambu Betung (Dendrocalamus asper Backer Ex Heyne) Terhadap Pertumbuhan Semai
Sengon (Paraserianthes falcataria (L.) Nielsen)., Skripsi, Fakultas Kehutanan, IPB, Bogor.

Marmadion, T., Purnamaningsih, S, L., dan Kuswanto., (2014). Penampilan Delapan Galur Kacang Panjang (Vigna sesquipedalis L. Fruwirth) Pada Dua Musim Tanam, Jurnal Produksi Tanaman, 2 (3) :230-238.

Ralahalu, M, A., Hehanussa, M, L., Oszaer, L, L. (2013). Respons Tanaman Cabai Besar (Capsicum annuum L.) Terhadap Pemberian Pupuk Organik Hormon Tanaman Unggul, Agrologia, 2 (2): 144-150.

Setiyono, A, E, (2015). Pengaruh Umur dan Dosis Pupuk Kandang Limosin terhadap Pertumbuhan dan Hasil Tanaman Kacang Panjang ( Vigna sinensis L. ), Agrotech, 2 (1), ISSN 2355-195.

Yeremia, E., (2016). Pengaruh Konsentrasi Mikroorganisme Lokal (MOL) dari Rebung Bambu terhadap Pertumbuhan Tanaman Sawi Caisim (Brassica juncea L.), Skripsi, Universitas Sanata Dharma, Yogyakarta. 